\title{
PEMANFAATAN GAMBIR SEBAGAI BAHAN DASAR PEMBUAT TINTA SPIDOL RAMAH LINGKUNGAN
}

\section{The Utilization of Gambier as an Eco-Friendly Base Material of Marker Ink}

\author{
Inda Three Anova* dan Hendri Muchtar \\ Balai Riset dan Standardisasi Industri Padang \\ JI. Raya LIK No. 23 Ulu Gadut Padang, Indonesia \\ * e-mail: indova99@gmail.com
}

Diterima: 25 September 2017, revisi akhir: 21 Desember 17 dan disetujui untuk diterbitkan: 22 Desember 2017

\begin{abstract}
ABSTRAK
Gambir dapat digunakan sebagai bahan baku pembuatan tinta spidol yang ramah lingkungan. Penelitian ini bertujuan untuk menghasilkan tinta spidol alternatif yang lebih aman bagi lingkungan dan kesehatan manusia. Tinta yang diproduksi saat ini pada umumnya masih mengandung volatile organic compound yang merupakan bahan kimia yang dapat merusak kesehatan. Pembuatan tinta dilakukan dalam beberapa tahap yaitu persiapan bahan baku gambir, pengekstrakan gambir, pembuatan pigmen warna, pembuatan formula tinta, dan dilanjutkan dengan pengadukan menggunakan alat high speed homogenizer untuk formula terbaik. Variasi kecepatan pengadukan adalah 1000, 1500, $2000 \mathrm{rpm}$ dan lama pengadukan 10, 20, 30 menit. Hasil penelitian menunjukkan bahwa tinta spidol yang terbaik diperoleh dari proses homogenisasi dengan waktu pengadukan 30 menit pada kecepatan $1000 \mathrm{rpm}$. Komposisi pigmen gambir 85\%, gliserin $3 \%$, polietylen glikol $2 \%$, dan propilen glikol $5 \%$ serta penambahan pengawet kristal violet $1 \%$. Karakteristik tinta spidol berupa partikel dengan ukuran 15,44 d.nm dengan indek polidiversitas 0,186 dan berat jenis 1,0254, tinta berwarna hitam, homogen, tulisan tidak terputus-putus dan waktu kering 6 menit.
\end{abstract}

Kata kunci: ekstrak gambir, pigmen, tinta spidol

\section{ABSTRACT}

Gambier can be used as a raw material for the manufacture of eco-friendly ink. This study was aimed to produce an alternative marker ink which is safer for the environment and human health. The current ink products generally contain volatile organic compound the chemical that can damage health. The study was done in several stages, raw material preparation, gambier extraction, color pigment making, ink formulation, and continued with stirring by used a high-speed homogenizer for the best formula. Variations of stirring speed were 1000, 1500, $2000 \mathrm{rpm}$ and stirring time 10, 20, 30 minutes. The results showed that the best ink was obtained from the homogenization process with stirring time 30 minutes and speed $1000 \mathrm{rpm}$. The composition of gambier pigment $85 \%$, glycerol 3\%, polyethylene glycol $2 \%$, propylene glycol 5\%, and the addition of preservatives crystal violet $1 \%$. The characteristics of markers ink were size particles $15.44 \mathrm{~d} . \mathrm{nm}$ with a poly diversity index 0.186 and specific gravity 1.0254, black color ink, homogeneous, writings were not disjointed, and 6 minutes dry time.

\section{Keywords: extract gambier, pigment, marker ink}

\section{PENDAHULUAN}

Bahan yang digunakan dalam pembuatan tinta meliputi pewarna pigmen (zat warna/dye), bahan pengikat varnish, pelarut dan aditif atau bahan penolong. Pigmen berfungsi sebagai pemberi warna dianggap sebagai penyusun utama tinta. Resin mengikat tinta bersama-sama ke dalam lapisan film dan mengikatnya ke 
permukaan. Pelarut digunakan untuk membuat aliran tinta sehingga bisa dipindahkan ke permukaan cetak, dan aditif berfungsi untuk membuat sifat fisik tinta agar sesuai dengan situasi yang berbeda (Ahmed, 2007; Antono Adhi, 2013; Wasono, 2008).

Salah satu produk yang dapat digunakan untuk menulis adalah tinta spidol. Spidol banyak digunakan terutama dalam kehidupan sehari-hari. Tinta spidol mengandung bahan berbahaya, beberapa diantaranya memilki kadar VOC (Volatile Organic Compound) yang cukup tinggi. Salah satu jenis $V O C$ yang terdapat dalam tinta spidol adalah xylene atau dimetilbenzene digunakan dalam industri dan teknologi medis sebagai pelarut.

Xylene adalah zat yang menimbulkan bau khas pada spidol, efek jangka pendek dari xylene bisa mengganggu pernapasan, pusing, sakit kepala dan kehilangan memori jangka pendek. Sedangkan efek jangka panjang dapat menyebabkan kerusakan otak permanen dan kerusakan hati, ginjal dan sistem saraf pusat (Ratnasari et al., 2013; Suhartini et al., 2012).

Tinta spidol pada dasarnya memiliki warna hitam dan mengandung karbon. Banyak sekali komponen alam di sekitar kita yang dapat dimanfaatkan menjadi bahan dasar pembuatan tinta spidol dan tentunya memiliki nilai ekonomis yang tinggi.

Penelitian pemanfaatan bahan ramah lingkungan dari tanaman untuk pembuatan tinta seperti kunyit dan bit telah dilakukan oleh (Kumar et al., 2012), sedangkan empat pewarna alami, annatto, cutch (Acasia catechu) menghasilkan warna (natural brown), kulit buah delima, dan golden dock, digunakan sebagai pewarna untuk ink jet tinta berbasis air pada pencetakan tekstil digital (Savvidis et al., 2014). Dari tanaman mikro algae merah dapat diperoleh pigmen warna yang dapat digunakan untuk bahan makanan, kosmetik dan obat-obatan (Arad and Yaron, 1992). Pembuatan tinta printer berbasis bahan alami dan ramah lingkungan dari kulit manggis dan kunyit (Ratnasari et al., 2013).

Salah satu bahan alam potensial yang dapat digunakan sebagai sumber pewarna pengganti bahan sintetis yang memiliki peluang besar dijadikan sebagai tinta adalah gambir (Uncaria gambir Roxb). Gambir mengandung senyawa tanin sebagai asam katechutannat (20-55\%) dan katechin (7-33\%), kedua senyawa ini merupakan senyawa komplek yang digolongkan ke dalam golongan fenol alam dengan struktur flavonoid. Gambir dalam suasana basa dapat memberikan warna merah darah, sedangkan jika ditambahkan $\mathrm{FeCl}_{3}$ alkoholik jenuh dan $\mathrm{NaOH}$ jenuh akan memberikan warna biru sampai hitam (Muchtar et al., 2014).

Pembuatan tinta dari gambir dengan menambah senyawa pengomplek besi (Fe) membentuk pigmen warna digunakan untuk tinta pemilu (Muchtar et al., 2014), dapat juga digunakan sebagai pigmen pewarna tinta cetak (Muchtar et al., 2015). Penggunaaan gambir sebagai bahan untuk pembuatan tinta dilakukan terlebih dahulu dengan melakukan ekstraksi pada gambir.

Beberapa peneliti telah melakukan proses ekstraksi terhadap gambir untuk mendapatkan senyawa fenolik katekin (Muchtar et al., 2010; Pambayun et al., 2007; Rauf et al., 2010; Yeni et al., 2014) Sedangkan pemanfaatan gambir sangat luas sebagai bahan baku dalam industri, seperti industri kosmetik, pewarna tekstil, food additif, dan industri farmasi (Rauf et al., 2010). Secara tradisional, gambir telah digunakan untuk penyamakan kulit, mewarnai tekstil (Failisnur dan Sofyan, 2014).

Pigmen yang diperoleh dari gambir dengan menambahkan senyawa besi seperti $\mathrm{FeSO}_{4}, \mathrm{FeCl}_{3}, \mathrm{FeNO}_{3}$ membentuk senyawa komplek memberikan warna khas (Muchtar et al., 2015). Pigmen gambir juga dapat dijadikan tinta stempel dengan menambahkan bahan penstabil glyserin (Silfia et al., 2015). Berdasarkan sifat warna tersebut di atas maka gambir dapat digunakan sebagai bahan baku dalam pembuatan tinta spidol dengan cara mengekstrak gambir tersebut dan memformulasikannya dengan bahan aditif sebagai penyusun tinta.

Penelitian ini bertujuan untuk mendapatkan teknologi pembuatan tinta spidol dengan memanfaatkan gambir sebagai bahan baku serta mengindentifikasi karakteristik tinta yang dihasilkan. 


\section{METODOLOGI PENELITIAN}

Bahan yang digunakan dalam penelitian adalah gambir asalan berasal dari Kabupaten 50 Kota, pelarut yang digunakan etanol teknis, senyawa pengomplek digunakan $\mathrm{FeCl}_{3}$ teknis, aquades, sebagai zat pembawa atau vehicle adalah Propylene Glycol (PG), sedangkan Politilen Glikol (PEG 400) dan gliserin berfungsi sebagai surfactan.

Alat-alat yang digunakan dalam penelitian adalah: mesin penghancur, alat spray dryer, magnetic stirrer, high speed homogenizer, peralatan gelas, kain saring, kertas saring, ember, wadah plastik. Peralatan uji meliputi Particle Size Analitical Instrument Vasco S/N (PSA), alat pengujian Scanning Electron Microscopy (SEM), alat uji berat jenis, kekentalan dan tegangan permukaan.

\section{Persiapan Bahan Baku Gambir}

Gambir asalan dihaluskan sehingga mempunyai ukuran lebih kecil. Air mendidih ditambahkan sampai semua bahan gambir larut sempurna. Saring kotoran yang ada dengan menggunakan kain saring, lakukan penyaringan berulang 2 sampai 3 kali. Keringkan gambir dengan menggunakan alat spray dryer, gambir yang telah kering siap digunakan untuk pembuatan pigmen dari tinta gambir.

\section{Pembuatan pigmen tinta}

Gambir yang telah dikeringkan ditambahkan pelarut etanol dengan perbandingan 1:3 (satu bagian berat gambir dalam tiga bagian volume pelarut etanol). Dilakukan pengadukan menggunakan strirrer dengan kecepatan 500 rpm selama 5 jam, dimaserasi selama 1 malam, kemudian saring dengan kertas saring sehingga didapatkan ekstrak gambir dalam etanol. Ekstrak gambir lalu ditambahkan secara tetes demi tetes senyawa pengomplek sebanyak $60 \% \mathrm{FeCl}_{3}$ jenuh dalam alkohol dari jumlah ekstrak yang didapatkan sambil terus dilakukan pengadukan. Kemudian tambahkan kristal violet sebanyak $1 \%$ dari volume, diaduk terus dengan kecepatan 500 rpm selama \pm 5 jam sehingga didapatkan pigmen tinta spidol dari gambir. Formulasi tinta spidol dibuat dengan menambahkan bahanbahan seperti gliserin, PEG 400, PG dan aquades. Selanjutnya formulasi tinta spidol sebagaimana ditampilkan pada Tabel.1.

Tabel.1 Formula tinta

\begin{tabular}{cccccc}
\hline Formula & \multicolumn{5}{c}{ Penambahan $(\%$ v/v) } \\
\cline { 2 - 6 } & Pigmen & Gliserin & PEG & Aquades & PG \\
\hline Tinta 1 & 45 & 3 & 2 & 45 & 5 \\
Tinta 2 & 50 & 3 & 2 & 40 & 5 \\
Tinta 3 & 55 & 3 & 2 & 35 & 5 \\
Tinta 4 & 60 & 3 & 2 & 30 & 5 \\
Tinta 5 & 65 & 3 & 2 & 25 & 5 \\
\hline
\end{tabular}

\section{Karakteristik Produk Tinta}

Karakteristik produk tinta sebelum proses homogenisasi meliputi: warna tinta, berat jenis pada suhu $28^{\circ} \mathrm{C}$, waktu kering hasil tulisan, viskositas, tegangan permukaan, kestabilan tinta dan homogenitas secara visual. Pengukuran distribusi dan ukuran partikel dengan metoda PSA (Particle size analysis). Pengukuran distribusi dan ukuran partikel merupakan salah satu bagian dari karakteristik pigmen tinta. Ukuran partikel akan mempengaruhi secara langsung terhadap sifat partikel tersebut. Penentuan distribusi dan ukuran partikel dilakukan untuk mengetahui perbedaan hasil variasi kecepatan dan waktu pengadukan. Uji morfologi partikel tinta dengan alat SEM setelah dilakukan homogenisasi. Untuk uji organoleptik tinta dilakukan pengamatan terhadap warna, daya hapus, dengan kategori susah jika tulisan dihapus dengan menggunakan penghapus masih tampak bekas tinta, kategori mudah jika tulisan yang ditulis dihapus hilang tanpa bekas. waktu kering tinta dan kestabilan/terputus atau tidak sewaktu ditulis.

\section{Homogenisasi Tinta}

Terhadap tinta dengan formula terbaik dilakukan pengadukan sampai semua bahan dalam formulasi tercampur merata dan tinta homogen, ditandai dengan tidak adanya endapan ataupun gumpalangumpalan pigmen. Tinta spidol yang telah diformulasikan tersebut selanjutnya diberi perlakuan waktu dan kecepatan pengadukan dengan menggunakan alat High Speed Homogenizer (HSH), sehingga 
didapatkan partikel-partikel tinta spidol dalam bentuk yang lebih halus dan homogen dengan rancangan perlakuan waktu pengadukan ( $\mathrm{T}$ ) dan kecepatan putaran (V). Waktu pengadukan terdiri dari 10 menit (T1), 20 menit (T2), dan 30 menit (T3). Kecepatan putaran pengadukan terdiri dari 1000 rpm (V1), 1500 rpm (V2), V3 2000 rpm (V3). Setelah dilakukan sesuai dengan perlakuan di atas, tinta dikemas ke dalam botol-botol, ditutup rapat, dan siap untuk dilakukan pengujian fisika.

\section{HASIL DAN PEMBAHASAN}

\section{Analisis Viskositas, Berat Jenis, dan Tegangan Permukaan}

Hasil pengujian viskositas, berat jenis dan tegangan permukaan sebelum proses homogenisasi dapat dilihat pada Tabel 2. Nilai viskositas atau kekentalan tertinggi didapatkan untuk formula tinta nomor 3 dan viskositas terendah didapatkan untuk formula tinta nomor 5. Dari hasil dapat dikatakan bahwa penambahan akuades mempengaruhi kekentalan dari tinta yang dihasilkan, dimana pada formula persentase pemakaian aquades semakin sedikit, nilai viskositasnya akan semakin kecil.

Tabel 2. Hasil pengujian viskositas, berat jenis dan tegangan permukaan.

\begin{tabular}{cccc}
\hline Formula & $\begin{array}{c}\text { Viskositas } \\
(C p)\end{array}$ & $\begin{array}{c}\text { Berat } \\
\text { Jenis } \\
\left(\mathrm{gr} / \mathrm{cm}^{3}\right)\end{array}$ & $\begin{array}{c}\text { Tegangan } \\
\text { Permukaan } \\
(\mathrm{mN} / \mathrm{m})\end{array}$ \\
\hline Tinta 1 & 5.5 & 1,0260 & 0,3405 \\
Tinta 2 & 6,0 & 1,0250 & 0,3852 \\
Tinta 3 & 6,2 & 1,0278 & 0,1324 \\
Tinta 4 & 5,9 & 1,0212 & 0,3827 \\
Tinta 5 & 5,4 & 1.0210 & 0,3078 \\
Tinta di & & & \\
pasaran & 5,2 & 1.0010 & 0,2482 \\
\hline
\end{tabular}

Nilai viskositas sangat mempengaruhi kualitas tinta. Tinta tidak boleh terlalu kental, karena akan sulit mengalir saat digunakan. Tinta pun tidak boleh terlalu encer karena kepekatan warna tinta yang dihasilkan akan berkurang. Nilai viskositas yang paling mendekati untuk nilai tinta spidol adalah tinta formula nomor 5 .
Berat jenis tinta spidol dari semua formula yang diuji tidak banyak perbedaan satu sama lainnya dan tidak tampak pengaruh penambahan persentase aquades dan pemakaian pigmen. Apabila dibandingkan dengan tinta di pasaran nilai berat jenis tinta dari gambir ini masih lebih tinggi.

Nilai tegangan permukaan tertinggi terdapat pada formula nomor 2 dan yang terendah terdapat pada formula nomor 3 . Nilai tegangan permukaan yang mendekati nilai tegangan permukaan tinta di pasaran adalah tinta nomor 5. Nilai tegangan permukaan sangat mempengaruhi kemampuan tinta melekat pada whiteboard, apakah tinta dapat bersifat permanen atau tidak (Suhartini et al., 2012). Besarnya tegangan permukaan dipengaruhi oleh beberapa faktor, seperti jenis cairan, suhu, tekanan, massa jenis, konsentrasi zat terlarut, dan kerapatan. Jika cairan memiliki molekul besar seperti air, maka tegangan permukaannya juga besar (Muchtar et al., 2015).

Salah satu faktor yang mempengaruhi besarnya tegangan permukaan adalah massa jenis/densitas (D). Semakin besar densitas berarti semakin rapat muatanmuatan atau partikel-partikel dari cairan tersebut. Kerapatan partikel ini menyebabkan makin besarnya gaya yang diperlukan untuk memecahkan permukaan cairan tersebut. Hal ini karena partikel yang rapat mempunyai gaya tarik menarik antar partikel yang kuat. Sebaliknya cairan yang mempunyai densitas kecil akan mempunyai tegangan permukaan yang kecil pula (Muchtar et al., 2015).

Hasil pengujian berat jenis setelah proses homogenisasi berkisar antara 1,001 sampai $1,0289 \mathrm{gr} / \mathrm{cm}^{3}$. Nilai yang didapatkan dari semua formula tidak banyak perbedaan satu sama lainnya dan tidak terlihat pengaruh pemakaian variasi kecepatan homogenisasi.

Nilai berat jenis tinta jika dibandingkan dengan nilai berat jenis tinta spidol whiteboard masih belum mendekati dengan nilai berat jenis 1,001. Berdasarkan SNI tinta cap dengan nomor 06-1567-1999, dipersyaratkan berat jenis tinta cap adalah minimal 1. 


\section{Uji Organoleptik pada Whiteboard sebelum Proses Homogenisasi}

Pengamatan warna seperti pada Tabel 3 memperlihatkan bahwa tinta belum berwarna hitam, tapi berwarna hijau kehitaman setelah dituliskan pada whiteboard dan bila dibandingkan dengan tinta whiteboard masih belum mendekati.

Pengamatan daya hapus tinta juga belum menunjukan seperti yang diharapkan bila dibandingkan dengan tinta whiteboard. Tinta setelah dituliskan pada whiteboard susah dihapus, masih mengotori whiteboard, dan meninggalkan jejak yang masih bisa dibaca samar-samar. Demikian juga untuk waktu kering tinta masih jauh dari yang diharapkan, dimana waktu kering tinta sangat lama dan segera setalah dituliskan pada whiteboard tinta akan mengalir ke bawah sehingga akan mengotori whiteboard apabila tinta dihapus.

Tabel 3. Pengamatan organoleptik tinta spidol sebelum dihomogenisasi.

\begin{tabular}{lllll}
\hline Formula & Warna & $\begin{array}{c}\text { Daya } \\
\text { hapus }\end{array}$ & $\begin{array}{c}\text { Waktu } \\
\text { Kering } \\
\text { (menit) }\end{array}$ & $\begin{array}{c}\text { Kestabilan } \\
\text { saat } \\
\text { ditulis }\end{array}$ \\
\hline Tinta 1 & $\begin{array}{l}\text { belum } \\
\text { Hitam }\end{array}$ & Susah & 10 & $\begin{array}{l}\text { Belum } \\
\text { stabil }\end{array}$ \\
\hline Tinta 2 & $\begin{array}{l}\text { belum } \\
\text { Hitam }\end{array}$ & Susah & 9 & $\begin{array}{l}\text { Belum } \\
\text { stabil }\end{array}$ \\
\hline Tinta 3 & $\begin{array}{l}\text { belum } \\
\text { hitam }\end{array}$ & Susah & 9 & $\begin{array}{l}\text { Belum } \\
\text { stabil }\end{array}$ \\
\hline Tinta 4 & $\begin{array}{l}\text { belum } \\
\text { hitam }\end{array}$ & Susah & 7 & $\begin{array}{l}\text { Belum } \\
\text { stabil }\end{array}$ \\
\hline Tinta 5 & $\begin{array}{l}\text { Agak } \\
\text { Hitam }\end{array}$ & Susah & 7 & $\begin{array}{l}\text { Agak } \\
\text { stabil }\end{array}$ \\
\hline $\begin{array}{l}\text { Tinta di } \\
\text { pasaran }\end{array}$ & Hitam & Mudah & 5 & Stabil \\
\hline
\end{tabular}

Pada pengamatan homogenitas dan kestabilan tinta pada whiteboard tampak bahwa tinta setelah dituliskan cukup homogen pada keseluruhan formula, namun tidak stabil atau sering terputusputus alirannya saat dituliskan pada whiteboard sehingga tulisan pada whiteboard tampak tidak merata atau hilang sebagian.

\section{Uji Organoleptik pada Whiteboard Setelah Proses Homogenisasi}

Pengamatan warna tinta setelah proses homogenisasi ditampilkan pada Tabel 4. Tinta sudah berwarna hitam setelah dituliskan pada whiteboard dan bila dibandingkan dengan tinta whiteboard sudah mulai mendekati/hampir sama. Hal ini berbeda bila dibandingkan dengan warna tinta pada penelitian sebelumnya yang belum berwarna hitam dan masih berwarna hijau kehitaman setelah dituliskan pada whiteboard. Perubahan warna menjadi hitam ini pada whiteboard tampak setelah beberapa saat tinta dituliskan pada whiteboard (pertamanya masih seperti tampak agak bening /kurang hitam), dan tidak langsung seperti halnya tinta whiteboard yang telah beredar di pasaran.

Pengamatan terhadap warna untuk semua perlakuan tinta memberikan warna yang relatif sama (hitam) dan tampak ada pengaruh lama pengadukan dan variasi kecepatan penggunaan alat $\mathrm{HSH}$. Ini sangat berhubungan dengan ukuran dari partikel tinta yang didapatkan, kemungkinan dengan semakin kecilnya ukuran warnanya semakin tampak baik dan rata.

Sementara untuk pengamatan daya hapus tinta untuk semua perlakuan masih belum menunjukkan kemajuan bila dibandingkan dengan tinta whiteboard, dimana tinta setelah dituliskan pada whiteboard masih susah dihapus, masih mengotori whiteboard dan meninggalkan jejak yang masih bisa dibaca samar-samar. Pada pengamatan daya hapus tinta ini tampak bahwa tinta sangat sulit sekali dihapus, dan baru mulai hilang setelah dibersihkan berulang kali menggunakan alkohol. Dalam hal ini mungkin bisa dijadikan acuan untuk menggunakan jenis tinta ini kearah jenis tinta yang permanen. Nilai tegangan muka sangat mempengaruhi kemampuan tinta melekat pada whiteboard, apakah tinta dapat bersifat permanen atau tidak.

Waktu kering tinta juga masih jauh dari yang diharapkan, dimana waktu kering tinta sangat lama dan segera setelah dituliskan pada whiteboard tinta akan mengalir ke bawah sehingga akan mengotori whiteboard apabila tinta dihapus. Hal ini juga menjadikan dilema dalam memformulasikan tinta spidol yang optimal. Pada penelitian sebelumnya tinta dibuat dengan memiliki kekentalan yang tinggi. Tinta tersebut juga memberikan waktu 
kering yang lebih lama lagi, sementara dalam penelitian peningkatan mutu tinta spidol ini dibuat tinta yang memilki viskositas yang lebih rendah/agak encer, tapi ternyata terkendala tinta menjadi agak meleleh/turun setelah dituliskan pada whiteboard sebelum mengering.

Tabel 4. Pengamatan organoleptik Tinta spidol setelah dihomogenizer.

\begin{tabular}{ccccc}
\hline $\begin{array}{c}\text { Kode } \\
\text { sampel }\end{array}$ & Warna & $\begin{array}{c}\text { Daya } \\
\text { hapus }\end{array}$ & $\begin{array}{c}\text { Waktu } \\
\text { Kering } \\
\text { (menit) }\end{array}$ & $\begin{array}{c}\text { Kestabilan } \\
\text { saat ditulis }\end{array}$ \\
\hline T1V1 & Hitam & Susah & 5 & Stabil \\
T1V2 & Hitam & Susah & 5 & Stabil \\
T1V3 & Hitam & Susah & 6 & Stabil \\
T2V1 & Hitam & Susah & 5 & Stabil \\
T2V2 & Hitam & Susah & 5 & Stabil \\
T2V3 & Hitam & Susah & 6 & Stabil \\
T3V1 & Hitam & Susah & 6 & Stabil \\
T3V2 & Hitam & Susah & 6 & Stabil \\
T3V3 & Hitam & Susah & 6 & Stabil \\
Tinta di & Hitam & Mudah & 5 & Stabil \\
pasaran & & & & \\
\hline
\end{tabular}

Pada pengamatan kehomogenan dan kestabilan tinta pada whiteboard sudah tampak bahwa tinta setelah dituliskan cukup homogen pada keseluruhan formula, sudah agak stabil saat dituliskan pada whiteboard, sehingga tampak pada whiteboard tulisan yang mulai baik. Untuk pengamatan organoleptik tinta dapat dilihat pada Gambar 1.

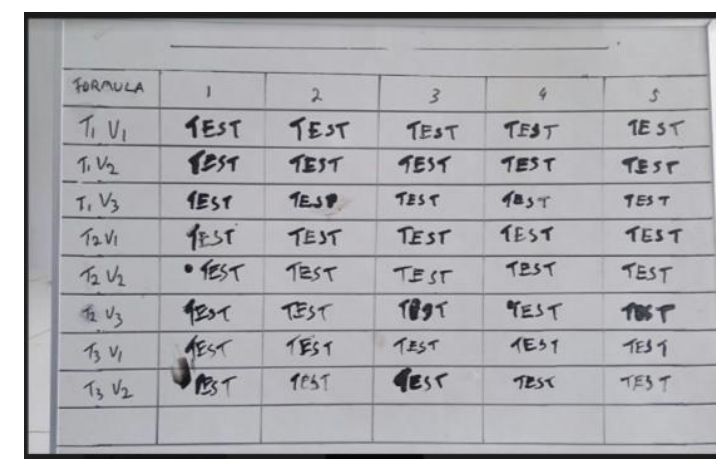

Gambar 1. Pengamatan organoleptik Tinta spidol setelah homogenisasi

\section{Pengukuran Distribusi dan Ukuran Partikel dengan Metoda Partikel Size Analisis (PSA)}

Hasil rata-rata ukuran partikel tinta dengan menggunakan metode pengujian particle size analysis (PSA) sebelum dilakukan homogenisasi seperti pada Tabel 5. Ukuran rata-rata partikel tinta yang didapatkan antara masing-masing formula sangat berbeda jauh, dimana ukuran partikel tinta berkisar diantara 96,45 nm $654,24 \mathrm{~nm}$.

Tabel 5. Hasil rata-rata ukuran partikel tinta dengan PSA.

\begin{tabular}{ccc}
\hline No & Formula & $\begin{array}{c}\text { Ukuran rata-rata Partikel } \\
(\mathrm{nm})\end{array}$ \\
\hline 1 & Tinta 1 & 240.61 \\
2 & Tinta 2 & 96.45 \\
3 & Tinta 3 & 516.59 \\
4 & Tinta 4 & 654.24 \\
5 & Tinta 5 & 363.09 \\
6. & Tinta di & 391.40 \\
& pasaran & \\
\hline
\end{tabular}

Hasil analisis ukuran partikel dengan menggunakan PSA setelah dilakukan pengadukan dengan menggunakan $\mathrm{HSH}$ dijelaskan pada Tabel 6. Dari Tabel 6, dapat dilihat bahwa perlakuan perbedaan waktu pengadukan dan kecepatan pada pembuatan nano partikel tinta spidol dari gambir dengan menggunakan alat $\mathrm{HSH}$ berpengaruh pada ukuran partikel tinta yang dihasilkan. Ukuran partikel tinta spidol yang dihasilkan berkisar dari 42,21 d.nm 15,11 d.nm, dimana ukuran partikel terkecil dihasilkan pada perlakuan T3V2 dan ukuran partikel terbesar pada perlakuan T1V1.

Tabel 6. Hubungan ukuran partikel dari beberapa variasi kecepatan dan waktu pengadukan dengan homogenizer.

\begin{tabular}{lcc}
\hline No & Formula & $\begin{array}{c}\text { Ukuran rata-rata Partikel } \\
\text { (d.nm) }\end{array}$ \\
\hline 1 & T1V1 & 42,21 \\
2 & T1V2 & 23,50 \\
3 & T1V3 & 23,85 \\
4 & T2V1 & 18,79 \\
5 & T2V2 & 16,79 \\
6 & T2V3 & 16,00 \\
7 & T3V1 & 15,44 \\
8 & T3V2 & 15,11 \\
9 & T3V3 & - \\
10. & WB & 391.40 \\
\hline
\end{tabular}

Hasil pengukuran partikel yang dilakukan terhadap tinta adalah dalam bentuk cair sehingga partikel tinta tidak saling beraglomerasi/menggumpal. Selain itu hasil pengukuran yang didapatkan dari partikel tinta ini adalah dalam bentuk distribusi, sehingga hasil pengukuran dapat diasumsikan sudah menggambarkan 
keseluruhan kondisi sampel (Suprobo and Rahmi, 2015).

Dari Tabel 6 juga dapat dilihat bahwa dengan bertambahnya waktu dan kecepatan putaran alat $\mathrm{HSH}$ ukuran partikel tinta gambir yang dihasilkan semakin kecil, tapi pada beberapa perlakuan terakhir pengurangan ukuran ukuran partikel tinta gambir tidak berkurang terlalu signifikan lagi. Dari hasil tersebut tampak bahwa penambahan waktu dan kecepatan putaran tidak memberikan pengurangan ukuran partikel tinta yang didapatkan.

Hasil analisis indek polidispersitas beberapa tinta dpat dilihat pada Tabel 7 . Dari ke 6 sampel yang diuji nilai indeks polidispersitas antara 0,148 (T2V3) sampai 0,359 (T1V2). Hal ini menunjukkan bahwa semua perlakuan mempunyai nilai indeks polidispersitas yang kecil. Ini merupakan gambaran bahwa partikel tinta yang dihasilkan seragam dan homogen, kecuali sampel T3V2 dengan indeks polidispersitas jauh di atas 0,3.

Tabel 7.Hasil analisis Indek polidipersitas

\begin{tabular}{ccc}
\hline No & $\begin{array}{c}\text { Kode } \\
\text { sampel }\end{array}$ & Indek polidipersitas \\
\hline 1 & T1V1 & 0,250 \\
2 & T1V2 & 0,359 \\
3 & T1V3 & 0,346 \\
4 & T2V3 & 0,148 \\
5 & T3V1 & 0,186 \\
6 & T3V2 & 0,665 \\
\hline
\end{tabular}

Hasil uji ukuran partikel tinta spidol menurut sebaran kurva intensitas seperti pada Gambar 2. Sebaran rata-rata ukuran tinta 20,44 d.nm pada puncak angka $12,14 \%$. Dari gambar tampak bahwa kurva terlihat mulus pada satu puncak dan sebaran yang tampak menunjukan bahwa ukuran partikel tinta perlakuan T3V1 bermutu baik.

\section{Uji Morfologi SEM Pigmen Tinta Spidol}

Uji morfologi SEM dilakukan pada tinta spidol gambir yang telah dikeringkan. Uji morfologi SEM ini dilakukan untuk melihat bentuk fisik patikel-partikel tinta kering gambir setelah mendapatkan perlakuan perbedaan waktu dan kecepatan putaran pada alat $\mathrm{HSH}$. Gambar 3 menampilkan hasil analisis SEM terhadap tinta spidol yang telah dikeringkan dengan perlakuan terbaik pada kecepatan pengadukan dengan alat $\mathrm{HSH}$ sebesar $1000 \mathrm{rpm}$ selama waktu 30 menit (T3V1).

Result quality: Good

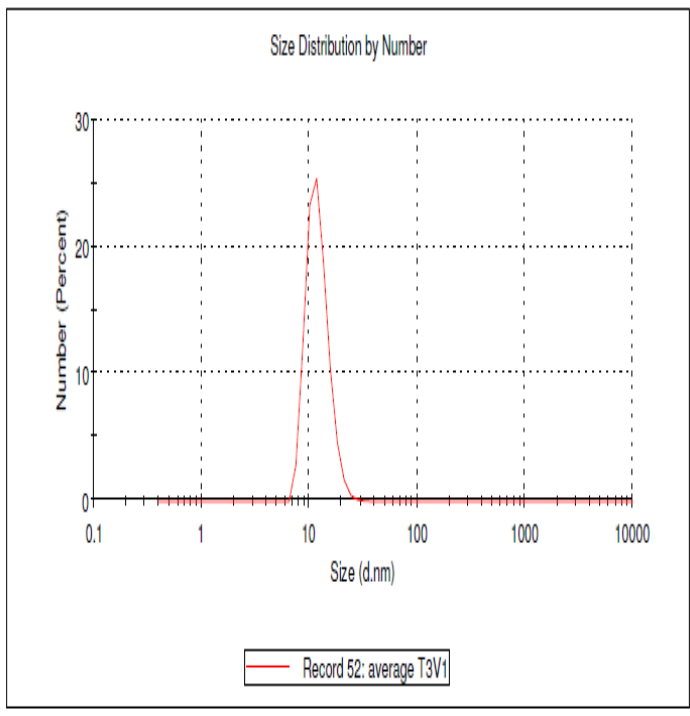

Gambar 2. Sebaran PSA tinta dengan variasi T3V1

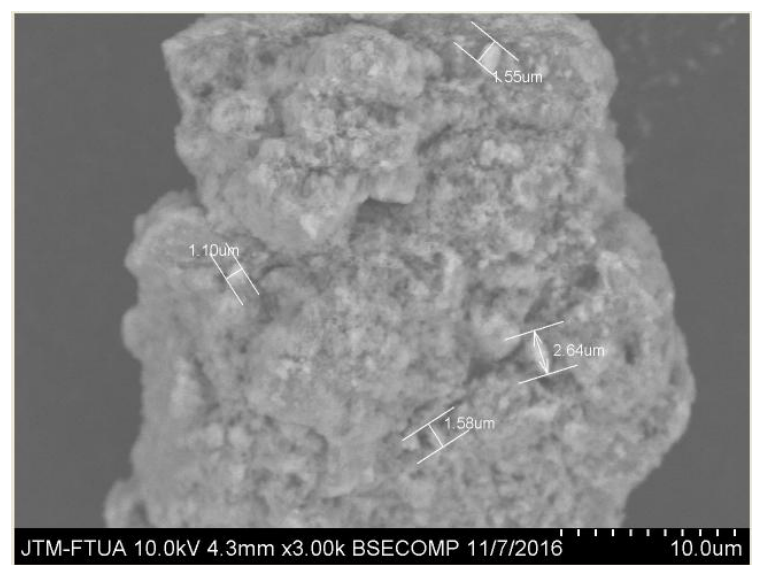

Gambar 3. Hasil analisis SEM tinta dengan pembesaran 3000 kali dengan variasi sampel T3V1.

Pada uji morfologi SEM tampak bahwa terdapat ukuran-ukuran partikel tinta yang tidak seragam, dan sebaran pigmen tinta yang tidak sama. Hal ini bisa terjadi karena tinta yang dilakukan foto uji SEM harus dikeringkan terlebih dahulu, sehingga akan merusak ukuran dari pigmen tinta yang dihasilkan setelah dijadikan dalam bentuk kering. 


\section{KESIMPULAN DAN SARAN.}

Hasil penelitian menunjukkan bahwa tinta spidol yang terbaik diperoleh dari proses homogenisasi dengan waktu pengadukan 30 menit pada kecepatan 1000 rpm (T3V1) dengan berat jenis tinta yang paling mendekati tinta whiteboard yaitu sebesar $1,0254 \mathrm{~g} / \mathrm{cm}^{3}$. Komposisi pigmen gambir $85 \%$, gliserin $3 \%$, polietylen glikol $2 \%$, dan propilen glikol $5 \%$ serta penambahan pengawet kristal violet $1 \%$.

Pada pengujian ukuran partikel tinta, nilai partikel tinta spidol yang paling halus didapatkan pada perlakuan T3V1, dengan ukuran partikel 15,44 d.nm, sedangkan bila dibandingkan dengan tinta whiteboard dengan nilai ukuran partikel lebih besar yaitu 391,40 d.nm tinta dengan perlakuan penggunaan alat $\mathrm{HSH}$ lebih halus dengan indek polidiversitas 0,186 . Tinta berwarna hitam, homogen, tulisan tidak terputusputus dan waktu kering 6 menit.

Pada uji morfologi SEM terdapat perbedaan rata-rata sebaran dan bentuk pigmen kering tinta spidol, ada yang besar dan ada yang kecil, dan tampak pigmen seperti bongkahan-bongkahan yang tidak rata. Hasil uji organoleptik tinta, rata-rata tinta masih sukar dihapus dan meninggalkan bekas/sukar untuk dibersihkan, warna hitam, waktu kering yang lama dan tinta tampak lebih homogen.

\section{UCAPAN TERIMA KASIH}

Penulis mengucapkan terima kasih kepada Yurnita atas kerjasama dan bantuannya dalam kegiatan penelitian ini.

\section{DAFTAR PUSTAKA}

Ahmed, S., 2007. Polymer science coating and adhesives tecnology of printing inks, in: Polymer Science. Dr Sharif Ahmed Materials Research Lab Dept of Chemistry Jamia Milia Islamia New Delhi- 110025, New Delh, p. 30.

Antono Adhi, S.A.S., 2013. Pengaruh Pemilihan Tinta Terhadap Kualitas Cetak Dalam Industri Percetakan Koran. J. Din. Tek. VII, 9-16.
Arad, S. (Malis), Yaron, A., 1992. Natural pigments from red microalgae for use in foods and cosmetics. Trends Food Sci. Technol. doi:10.1016/09242244(92)90145-M

Failisnur, Sofyan, 2014. Sifat tahan luntur dan intensitas warna kain sutera dengan pewarna alam gambir (Uncaria gambir Roxb) pada kondisi pencelupan dan jenis fiksator yang berbeda. J. Litbang Ind. 4, 1-8.

Kumar, M.R., Priya, P., Lakshmi, R., Vadivelu, A., Gopal, V., 2012. Formulation and Standardisation of Herbal Based Edible Ink 1, 252-254.

Muchtar, H., Anova, I.T., Ardinal, 2014. Pengaruh penggunaan senyawa pengomplek dan bahan tambahan terhadap mutu tinta pemilu dari ekstrak gambir (Uncaria gambir Roxb). J. Litbang Indsutri 4, 89-96.

Muchtar, H., Anova, I.T., Yeni, G., 2015. Pengaruh kecepatan pengadukan dan kehalusan gambir serta variasi komposisi terhadap beberapa sifat fisika dalam pembuatan tinta cetak. J. Litbang Indsutri 5, 131-139. doi:10.24960/jli.v5i2.674.131-139

Muchtar, H., Yeni, G., Hermianti, W., Diza, Y.H., 2010. Pembuatan konsentrat polifenol gambir (Uncaria gambir Roxb) sebagai bahan antioksidan pangan. $\mathrm{J}$. Ris. Ind. 4, 71-82.

Pambayun, R., Gardjito, M., Sudarmadji, S., Kuswanto, K.R., 2007. Kandungan fenol dan sifat antibakteri dari berbagai jenis ekstrak produk gambir (Uncaria gambir Roxb). Maj. Farm. Indones. 18, 141-146.

Ratnasari, E., Purwati, A.I., Tambunan, D.Y., Nugraha, G., Elis, S., 2013. CPU (colour print unit) sebagai inovasi tinta printer berbasis bahan alami dan ramah lingkungan 1-19.

Rauf, R., Santoso, U., Suparmo, 2010. Aktivitas penangkapan radikal DPPH ekstrak gambir (Uncaria gambir Roxb.). Agritech 30, 1-3.

Savvidis, G., Karanikas, E., Nikolaidis, N., Eleftheriadis, I., Tsatsaroni, E., 2014. 
Ink-jet printing of cotton with natural dyes. Color. Technol. 130, 200-204. doi:10.1111/cote.12087

Silfia, Muchtar, H., Failisnur, 2015. Pengaruh perbedaan persentase penambahan gliserin dan konsentrasi larutan ekstrak gambir terhadap beberapa sifat fisika dan kadar tanin tinta stempel. J. Litbang Indsutri 5, 5360.

Suhartini, N., Linguistika, Y., Wulansari, M., Budiyanto, E., Matematika, P., Biologi, P., Kimia, P., Yogyakarta, U.N., 2012. Pemanfaatan arang jerami sebagai bahan dasar pembuat tinta whiteboard yang ramah lingkungan. Pros. Semin. Nas. Penelitian, Pendidik. dan Penerapan MIPA, Fak. MIPA, Univ. Negeri Yogyakarta, 2 Juni 2012 1-6.
Suprobo, G., Rahmi, D., 2015. Pengaruh kecepatan homegenisasi terhadap sifat fisika dan kimia krim nanopartikel dengan metode high speed homogenization (HSH). J. Litbang Ind. 5, 1-12. doi:10.24960/jli.v5i1.661.1-12

Wasono, A.B., 2008. Teknik grafika dan industri grafika. Direktorat Jenderal Manajemen Pendidikan Dasar dan Menengah Departemen Pendidikan Nasional Tahun.

Yeni, G., Syamsu, K., Suparno, O., Mardliyati, E., Muchtar, H., 2014. Repeated extraction process of raw gambiers (Uncaria gambier Robx.) for the catechin production as an antioxidant. Int. J. Appl. Eng. Res. 9, 24565-24578. 